University of Nebraska - Lincoln

DigitalCommons@University of Nebraska - Lincoln

USDA National Wildlife Research Center - Staff Publications
U.S. Department of Agriculture: Animal and Plant Health Inspection Service

2-2011

\title{
Is Wildlife Going to the Dogs? Impacts of Feral and Free-roaming Dogs on Wildlife Populations
}

\author{
Julie K. Young \\ Utah State University, julie.k.young@aphis.usda.gov \\ Kirk A. Olson \\ University of Massachusetts - Amherst \\ Richard P. Reading \\ Denver Zoological Foundation \\ Sukh Amgalanbaatar \\ Institute of Biology at the Mongolian Academy of Sciences in Ulaanbaatar \\ Joel Berger \\ University of Montana - Missoula
}

Follow this and additional works at: https://digitalcommons.unl.edu/icwdm_usdanwrc

Young, Julie K.; Olson, Kirk A.; Reading, Richard P.; Amgalanbaatar, Sukh; and Berger, Joel, "Is Wildlife Going to the Dogs? Impacts of Feral and Free-roaming Dogs on Wildlife Populations" (2011). USDA National Wildlife Research Center - Staff Publications. 1387.

https://digitalcommons.unl.edu/icwdm_usdanwrc/1387

This Article is brought to you for free and open access by the U.S. Department of Agriculture: Animal and Plant Health Inspection Service at DigitalCommons@University of Nebraska - Lincoln. It has been accepted for inclusion in USDA National Wildlife Research Center - Staff Publications by an authorized administrator of DigitalCommons@University of Nebraska - Lincoln. 


\title{
Is Wildlife Going to the Dogs? Impacts of Feral and Free-roaming Dogs on Wildlife Populations
}

\author{
JULIE K. YOUNG, KIRK A. OLSON, RICHARD P. READING, SUKH AMGALANBAATAR, AND JOEL BERGER
}

In human-populated landscapes, dogs (Canis familiaris) are often the most abundant terrestrial carnivore. However, dogs can significantly disrupt or modify intact ecosystems well beyond the areas occupied by people. Few studies have directly quantified the environmental or economic effects of free-roaming and feral dogs. Here, we review wildife-dog interactions and provide a case study that focuses on interactions documented from our research in Mongolia to underscore the need for studies designed to best determine how dogs affect native wildlife and especially imperiled populations. We suggest additional research, public awareness campaigns, and the exclusion of dogs from critical wildlife habitat. The application of scientific findings to management and enhanced public outreach programs will not only facilitate recovery and maintenance of wildlife populations globally but also has the potential to reduce economic losses.

Keywords: Canis familiaris, endangered species, global threats, population ecology

M aintaining or restoring ecosystem health is a major conservation goal, but its achievement is challenged by many significant immediate and long-term threats, including habitat loss, infectious disease, and nonnative species. The impacts of some threats have been well studied, but the impacts of others remain less understood. For example, much attention has focused on free-ranging and feral cats (Felis catus; e.g., Patronek 1998), but free-roaming and feral dogs (Canis familiaris) receive less notice, despite being a major problem in many places and potential predators of or competitors with a wider variety of native species than cats (Feldmann 1974).

Little information exists on the environmental and economic effects of free-roaming and feral dogs, potentially hampering the efficacy of conservation initiatives. Few studies have focused on population-level impacts to endemic species associated with wildlife-dog interactions. Of the studies that have focused on these issues, most have found that dogs negatively affect native species. For example, domestic dogs were shown to have a significant effect on Ethiopian wolves (Canis simensis) through disease transmission and hybridization (Laurenson et al. 1998). However, Atickem and colleagues (2009) did not find evidence that dogs compete with Ethiopian wolves for prey and space (i.e., interference competition). Some studies have focused on human-related economics associated with free-roaming and feral dogs, such as those related to human cases of rabies infection in Asia (Knobel et al. 2005) and livestock depredation in the United States (NASS 1995). Although studies on the impacts of freeroaming and feral dogs have been limited in scope, they do suggest the repercussions to local economies may be comparable to those associated with well-studied threats such as infectious disease. One key difference, however, is that small changes in policy and human behavior with respect to dogs could profoundly reduce these costs.

Our goal is to review the nature of wildlife-dog interactions, drawing attention to the lack of overarching knowledge about impacts of free-roaming and feral dogs on native wildlife. We offer a case study detailing our own observations during research on endemic species in Mongolia. We then suggest ways to improve knowledge about the role of feral and free-roaming dogs in conservation issues.

\section{What are the ecological impacts of dogs?}

It is estimated that more than 500 million dogs occur sympatrically with humans worldwide (WHO-WSPA 1990). In some regions, dogs are used to facilitate hunting, protect property, or reduce human-wildlife conflicts by protecting livestock from people or predators (Khan 2009). Domestic dogs can also enhance noninvasive wildlife research and management methods (e.g., Cablk and Heaton 2006, Long et al. 2007). When neglected or no longer needed, dogs often become feral or free roaming. In some places, dogs are the most abundant carnivore and significantly disrupt ecosystems (Feldmann 1974, WHO-WSPA 1990).

Dogs spread disease, harass or kill wildlife, and compete with endemic species (table 1, figure 1). Because they carry transmissible pathogens for diseases such as rabies, parvovirus, and canine distemper virus (CDV), dogs can cause significant population declines of native, often endangered,

BioScience 61: 125-132. ISSN 0006-3568, electronic ISSN 1525-3244. (c) 2011 by American Institute of Biological Sciences. All rights reserved. Request permission to photocopy or reproduce article content at the University of California Press's Rights and Permissions Web site at www.ucpressjournals.com/ reprintinfo.asp. doi:10.1525/bio.2011.61.2.7

This article is a U.S. government work, and is not subject to copyright in the United States. 


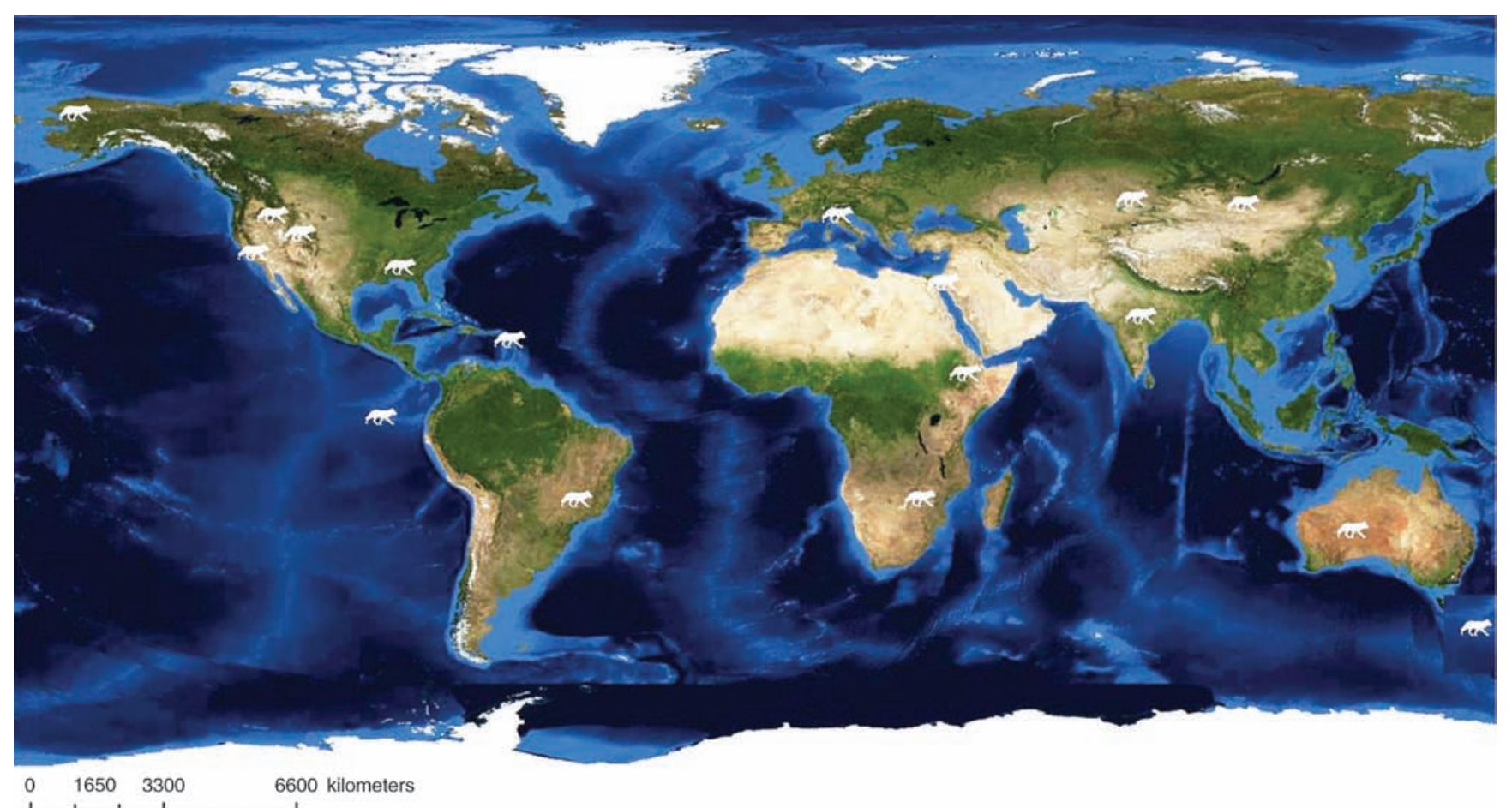

Figure 1. Global distribution of studies demonstrating negative impacts on prey species by free-roaming and feral dogs, many resulting in population declines of endemic species.

wildlife (Woodroffe 1999). For example, CDV was transmitted from domestic dogs to threatened Lake Baikal seals (Phoca sibirica), resulting in further population declines of the seals (Mamaev et al. 1995). Dogs come in close contact with both humans and wildlife, resulting in the potential transmission of zoonotic diseases that otherwise might not surface in humans (Salb et al. 2008). Not only are dogs an important source of pathogens of emerging diseases but they also act as a link for parasite exchange among humans, livestock, and wildlife (MacPherson 2005). In fact, dogs and cats share at least 60 parasite species with humans (MacPherson 2005).

Although the direct killing of wildlife is most apparent, many dogs also harass or chase endemic species, which results in increased stress and energetically costly behavior to native wildlife (Lenth et al. 2008). The mere presence of dogs also deters the use and habitation of those areas (Lenth et al. 2008) and can have deleterious effects on the breeding success of native species such as ungulates (Gingold et al. 2009). Gingold and colleagues (2009) found that no mountain gazelle (Gazella gazella) fawns survived after six months in pens with dogs present, suggesting the occurrence of dog predation. Dogs have been documented killing animals as small as rodents and as large as kudu (Tragelaphus strepsiceros; table 1; Green and Gipson 1994, CDW 1998). Dogs act as intraguild competitors (Boitani et al. 1995, Vanak and Gompper 2009): Where dogs roam freely, intraguild species (a) are less common (e.g., Indian foxes, Vulpes bengalensis; Vanak et al. 2009), (b) are killed by dogs (kit foxes, Vulpes macrotis; Ralls and White 1995), and (c) kill dogs (e.g., mountain lions, Puma concolor; Torres et al. 1996). When intraguild species kill dogs, human-wildlife conflict is worsened.

The impacts of dog predation in some cases may be more severe than those of wild predators. In one study conducted in the French Pyrenees, Bouvier and Arthur (1995) recorded 733 kills of domestic sheep, $91 \%$ of which were by freeroaming and feral dogs; brown bears (Ursus arctos) were responsible for the remaining $9 \%$. The extent to which these results may be applicable to wildlife species is unclear but raises the possibility of similarly higher predation rates by dogs, especially near human settlements. The problem may become more prevalent as human settlements continue to expand, because direct and indirect provisioning by humans creates high dog densities that may result in predation pressure on native wildlife, independent of fluctuations in prey population size. Artificially high densities of feral and free-roaming dogs may prevent the recovery of small prey populations (Banks and Bryant 2007), and even low densities of feral and free-roaming dogs may have severe impacts on wildlife populations. For example, population recovery efforts for kiwi (Apteryx australis) are hampered by high rates of mortality caused by dogs (70\% of the 194 mortalities studied by Pierce and Sporle 1997). This case is particularly interesting because a single free-roaming dog was implicated in the initial population decline (table 1; Taborsky 1988); however, the marauding dog was discovered only after radio-tagged kiwis were killed. Similarly, a study using genetic analysis to evaluate the diets of wolves (Canis lupus) in conflict with livestock producers found that fecal samples 


\begin{tabular}{|c|c|c|c|c|}
\hline Focal species & Dog type & Location & Impact of dogs & Source \\
\hline Free-roaming dog & $\mathrm{R}$ & Zimbabwe & Dogs killed 12 species, 8 native to the region & Butler et al. 2004 \\
\hline Dog & $\mathrm{R}$ & Ethiopia & Killed rodents, competed with Ethiopian wolves & Sillero-Zubiri and Gotelli 1994 \\
\hline Livestock guard dog & 0 & United States & Chased and killed native mammals and birds & $\begin{array}{l}\text { Green et al. 1984, Black } \\
\text { and Green } 1985 \text {, Timm and } \\
\text { Schmidt } 1990\end{array}$ \\
\hline Domestic sheep & $\mathrm{R}$ & Central Italy & Dogs killed 50 of 577 canid-killed sheep & Ciucci and Boitani 1998 \\
\hline Dog and cat & $\mathrm{R}$ & Southeast Brazil & Consumed native mammals & Campos et al. 2007 \\
\hline Dog & 0 & Colorado & $\begin{array}{l}\text { Small mammals, mule deer, and bobcat (Felis rufus) } \\
\text { avoided hiking trails with dogs; prairie dog (Cynomys } \\
\text { ludovicianus) densities lower near areas with dog use }\end{array}$ & Lenth et al. 2008 \\
\hline Dog & $\mathrm{F}$ & $\begin{array}{l}\text { Brasília National } \\
\text { Park, Brazil }\end{array}$ & $\begin{array}{l}\text { Dogs create edge effect, maned wolf and giant } \\
\text { anteater (Myrmecophaga tridactyla) avoid dogs }\end{array}$ & Lacerda et al. 2009 \\
\hline $\begin{array}{l}\text { White-tailed deer } \\
\text { (Odocoileus virginianus) }\end{array}$ & $\mathrm{F}$ & Alabama & Observed 16 chases, nuisance to adult deer & Causey and Cude 1980 \\
\hline $\begin{array}{l}\text { White-tailed and mule deer } \\
\text { (Odocoileus hemionus) }\end{array}$ & $\mathrm{R}$ & Idaho & Observed 39 chases, 12 deaths & Lowry and McArthur 1978 \\
\hline $\begin{array}{l}\text { Mountain gazelle } \\
\text { (Gazella gazella) }\end{array}$ & $\mathrm{R}$ & $\begin{array}{l}\text { South coast, } \\
\text { Israel }\end{array}$ & $\begin{array}{l}\text { Affected kid-to-female ratio, suppressed population, } \\
\text { affected space use }\end{array}$ & $\begin{array}{l}\text { Gingold et al. } 2009 \text {, } \\
\text { Manor and Saltz } 2004\end{array}$ \\
\hline $\begin{array}{l}\text { Blackbuck (Antilope } \\
\text { cervicapra) }\end{array}$ & $\mathrm{R}$ & India & $\begin{array}{l}\text { Killed fawns and competed with Indian wolf } \\
\text { (Canis lupus pallipes) }\end{array}$ & $\begin{array}{l}\text { Jhala and Giles 1991, } \\
\text { Jhala } 1993\end{array}$ \\
\hline Saiga (Saiga tatarica tatarica) & $\mathrm{R}$ & Kazakhstan & More than 10,000 saiga reportedly killed by dogs annually & Sludskii 1962 \\
\hline Musk ox (Ovibos moschatus) & $\mathrm{F}$ and $\mathrm{R}$ & Alaska & Harassed herds & Mech 1988 \\
\hline Red fox (Vulpes vulpes) & $\mathrm{F}$ & $\begin{array}{l}\text { Southwest } \\
\text { Australia }\end{array}$ & Dietary competition and fine-scale exclusion & Mitchell and Banks 2005 \\
\hline $\begin{array}{l}\text { San Joaquin kit fox } \\
\text { (Vulpes macrotis mutica) }\end{array}$ & $\mathrm{R}$ & California & One confirmed kill & Ralls and White 1995 \\
\hline Wallaby & $\mathrm{R}$ & $\begin{array}{l}\text { New South } \\
\text { Wales }\end{array}$ & Chased and killed wallabies & Meek 1999 \\
\hline Wild scavengers & $\mathrm{R}$ & Zimbabwe & Negatively affected vultures and wild carnivores & Butler and du Toit 2002 \\
\hline Native birds & 0 & $\begin{array}{l}\text { Southwest } \\
\text { Australia }\end{array}$ & Reduced bird diversity and abundance & Banks and Bryant 2007 \\
\hline $\begin{array}{l}\text { Indian vultures (Gyps } \\
\text { bengalensis and Gyps indicus) }\end{array}$ & $\mathrm{F}$ and $\mathrm{R}$ & India & Dogs replaced vultures at carcasses & Prakash et al. 2003 \\
\hline Kiwi (Apteryx australis) & $\mathrm{R}$ & New Zealand & $\begin{array}{l}\text { One dog killed } 600 \text { to } 800 \text { (of 1000) kiwis over } \\
\text { approximately six weeks }\end{array}$ & Taborsky 1988 \\
\hline $\begin{array}{l}\text { Wild turkey (Meleagris } \\
\text { gallopavo) }\end{array}$ & $\mathrm{F}$ and $\mathrm{R}$ & United States & $\begin{array}{l}\text { Review of studies throughout the United States where } \\
\text { dogs killed more wild turkeys than many or all other } \\
\text { predators }\end{array}$ & Miller and Leopold 1992 \\
\hline $\begin{array}{l}\text { Marine iguana } \\
\text { (Amblyrhynchus cristatus) }\end{array}$ & $\mathrm{F}$ & $\begin{array}{l}\text { Galápagos } \\
\text { Islands, Ecuador }\end{array}$ & Unsustainable predation & Kruuk and Snell 1981 \\
\hline $\begin{array}{l}\text { Rock iguana (Cyclura } \\
\text { carinata) }\end{array}$ & $\mathrm{R}$ & West Indies & Dogs were effective predators on iguana population & Iverson 1978 \\
\hline Chiru (Pantholops hodgsonii) & $\mathrm{R}$ & Tibet & Nineteen confirmed cases of dogs killing chiru & Schaller 1998 \\
\hline
\end{tabular}

F, feral; O, other dogs that were working dogs, off-leash pets under voice command, or experimentally on and off leash; R, free roaming.

collected as wolf scat were misidentified and were actually from dogs (Echegaray and Vilà 2010). Results suggested that, compared with wolves, free-roaming dogs consumed more livestock (Echegaray and Vilà 2010). These studies suggest that feral and free-roaming dogs have broad-scale negative impacts, though much of the evidence is merely a by-product of studies that set out to address other questions. Because few studies directly measure the effects of dogs on wildlife and livestock, deficiencies in understanding include population-level impacts, economic costs, and whether observed effects are additive or compensatory.

\section{Case study: Mongolian ungulates}

In areas of central Asia supporting relict species with diminished populations, free-roaming and feral dog populations may have profound effects. Nine endangered and threatened ungulate species occur in Mongolia, and we studied three of them: (1) Mongolian gazelles (Procapra gutturosa), 
(2) Mongolian saiga (Saiga tatarica mongolica), and (3) argali (Ovis ammon). These three species occupy areas where free-roaming dogs are relatively common (Clark et al. 2006). Most households in rural Mongolia own at least one dog (Buuveibaatar et al. 2009)_usually large and of mixed breed. Dogs are kept to protect homes but roam freely during the day (Buuveibaatar et al. 2009). Preliminary observations and radiotelemetry revealed evidence of indirect and direct interactions among the three endangered species and dogs (figure 2). Our observations of free-roaming dogs chasing and attacking argali, Mongolian saiga, and Mongolian gazelle are detailed here to highlight the need for studies targeting the direct threat that dogs may pose to these species.
Argali. Argali in Ikh Nart Nature Reserve, Dornogobi Aimag, were captured and radio-collared between 2002 and 2007 (Reading et al. 2003, 2005, Kenny et al. 2008). Collared argali were tracked for a minimum of two weeks each month and survival was monitored daily with binoculars and telemetry. All collars were equipped with mortality sensors. When an individual animal was found dead, a necropsy was performed to determine the cause of death and the surrounding area was searched for additional clues. In cases of predation, attempts were made to identify the predator species. Potential predators of argali include wolves, free-roaming dogs, foxes (Vulpes vulpes and Vulpes corsac), and snow leopards (Uncia uncia). Fox and snow leopard kills could normally be distinguished from those of other predators by

Mongolian gazelles. Observations of dogs interacting with Mongolian gazelles were made during a larger study of their ecology in Mongolia's eastern steppe region (Olson et al. 2005). In eastern Mongolia, we observed a free-roaming dog chasing a Mongolian gazelle calf not even one-month old, and on two occasions we observed packs of dogs giving chase to entire groups. This behavior disrupted and fragmented large, postcalving aggregations.

Mongolian saiga. Information on saiga mortalities by dogs was obtained and confirmed during conversations and interviews with local herders while we were conducting studies in the Shargyn-Govi Nature Reserve, western Mongolia (Berger et al. 2008, Buuveibaatar et al. 2009). From conversations, we learned that free-roaming dogs killed three saiga in the Sharga Nature Reserve during April 2007, and we heard several unconfirmed reports of dogs killing saiga throughout the year. In 2009, there were 2213 dogs within four soums (i.e., counties) inhabited by saiga (Buuveibaatar et al. 2009). During interviews, $17 \%$ of dog owners reported that their dogs roam freely, $25 \%$ of interview respondents have witnessed free-roaming dogs harassing saiga, and at least 11 respondents have witnessed dogs killing saiga (Buuveibaatar et al. 2009). Campaigns to remove stray dogs have resulted in killing of 482 dogs within the four soums over the last three years.

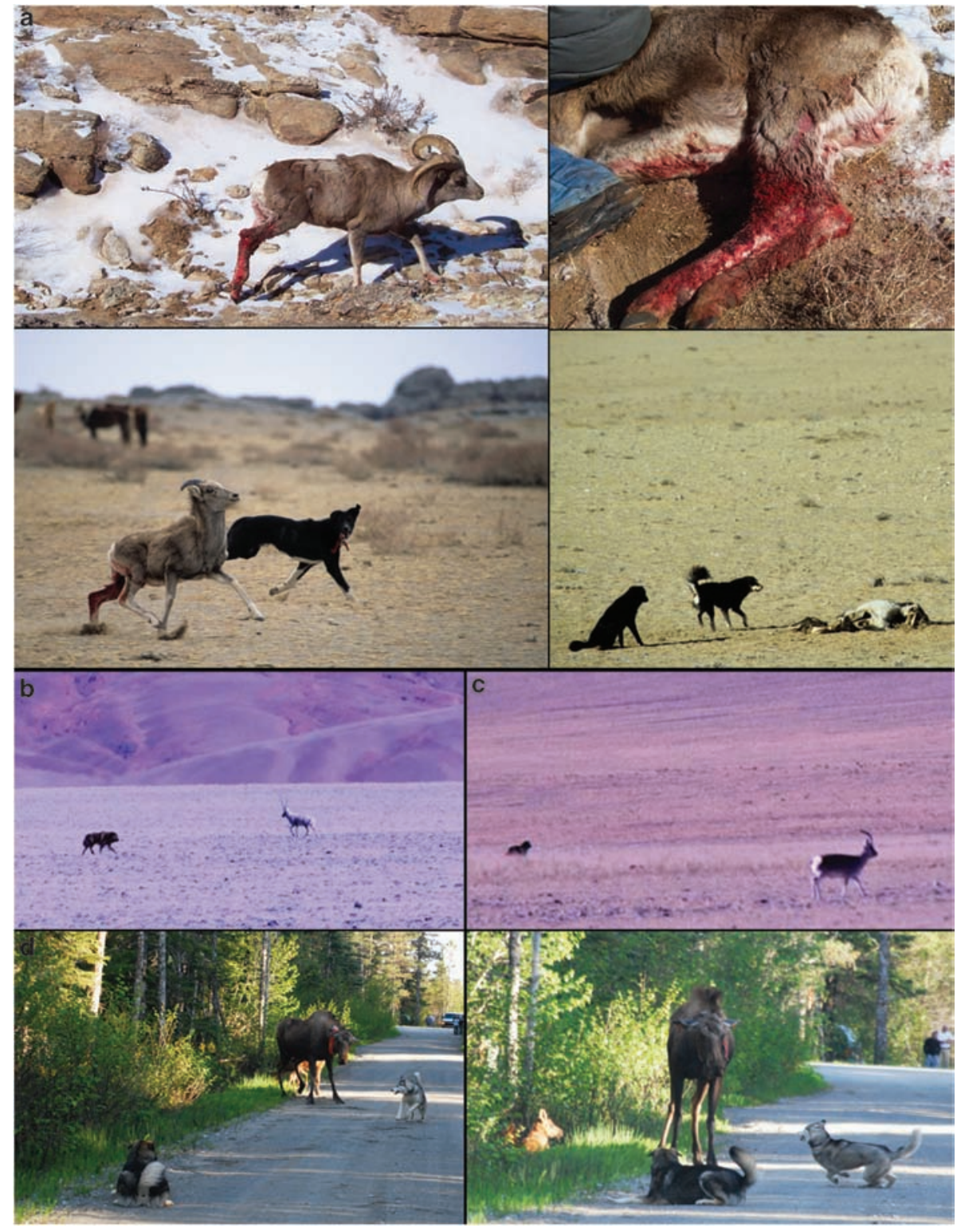

Figure 2. Free-roaming dogs (a) attack and kill argali in Mongolia, interact with (b) endangered chiru and (c) Tibetan gazelle in Tibet, and (d) harass a female moose with calves in Alaska. Moose photographs courtesy of Kevin White. 
a combination of signs, including the tracks, scat, and the distance between puncture wounds. However, kills made by either a wolf or by free-roaming or feral dogs could not be distinguished confidently in all cases, and were classified only as canid.

Dog predation in the Ikh Nart Nature Reserve was responsible for between $2.7 \%$ and $34.2 \%$ of GPS (global positioning system)-collared argali deaths $(n=25)$. Although only $2.7 \%$ were positively identified as dog kills, wolves were sighted just six times in eight years whereas free-roaming dogs were frequently observed. We also found or observed five uncollared argali killed by free-roaming dogs during the study period. The deaths of radio-collared argali during this study therefore suggest that dogs may be a large source of mortality.

\section{Recommendations to understand and reduce wildlife-dog interactions}

Nonnative species have long been recognized for their negative ecological effects (Elton 1958), and actions have been taken to reduce these impacts. Yet methods to reduce the damage caused by feral and free-roaming dogs are rarely considered. In the United States, laws exist in 44 states that allow prosecution of dog owners or the killing of dogs that chase or harass wildlife (Tischler 2007). Yet incidents rarely result in action. Agencies charged with responding to such problems are often unable to take action because they are understaffed or underfunded. By understanding the extent to which dogs affect wildlife populations, agencies could respond more efficiently to incidents (i.e., determining whether to take action in response to a given incident).

In light of growing evidence of the detrimental effects of dogs on wildlife and initial efforts to reduce these effects (Woodroffe 1999), we offer the following suggestions to help shift from anecdotes to understanding: (a) focused studies on wildlife-dog interactions and the impacts on wildlife populations, especially regarding endangered species; (b) public awareness campaigns to explain the impacts of dogs, help dog owners appreciate their role as wildlife stewards, and teach pastoralists how to train herding dogs and the urban public how to train companion dogs on hikes to not harass wildlife; and (c) opportunities to create policy that exclude free-roaming dogs from critical wildlife habitat, especially during sensitive periods (e.g., parturition) for species of concern.

\section{Need for directed studies}

More studies to assess population-level effects of dog predation on wildlife are needed. The ubiquity of our trans-Mongolian observations and global examples (e.g., figure 1) point to a need to understand the effects of dog predation relative to other sources of wildlife mortality, such as poaching or disease. Most data gathered to date are from personal observations and public accounts, or are gleaned indirectly from studies targeting other objectives (e.g., Echegaray and Vilà 2010). Studies designed and directed to measure the impacts of dogs will provide much needed information. If dogs are a major threat, then there is a need to change priorities in conservation thinking and action.

Studies are needed not only to understand the effect of dogs but also to learn the effects of dog removal and control programs on native wildlife species. In some areas, carnivores regulate populations of pest species that may otherwise have detrimental consequences for native species (Newsome 1990). In areas where top carnivores have already been removed, feral and free-roaming dogs may act as top predators (Prugh et al. 2009). Thus, it the possible that controlling dogs could have unintended negative consequences for wildlife by releasing populations of mesopredators such as feral cats. However, until studies are done, the effect of feral dogs on these nonnative pests will remain unknown.

Obtaining information on the direct and indirect effects of dogs is possible with today's technological advances. Modern methodology provides a range in cost and precision for evaluating potential effects, such that a study could be designed on the basis of specific needs and budget limitations. Noninvasive techniques such as camera traps can be used to estimate population size and monitor the population dynamics of dogs and potential prey species (e.g., O'Brien et al. 2003). Advances in genetics allow the identification of individual predators that attack or kill prey species (Williams et al. 2003), providing opportunities for selective removals and more efficient management of free-roaming and feral dogs. GPS radio collars can provide spatial information to enhance analyses of wildlife-dog interactions, similar to applications of GPS collars to wolfungulate interactions (e.g., Zimmerman et al. 2007). Photos from camera traps and spatial details from GPS collars may also help public awareness campaigns by providing dog owners with visual examples of the roaming capabilities of pets. These techniques could be employed to provide muchneeded information on the effects of free-roaming and feral dogs, while still providing basic biological information to test alternative hypotheses.

\section{Need for public awareness campaigns}

Conservation actions focused on reducing wildlife-dog interactions will be challenging because of public perceptions. Humans and dogs have close relationships in many societies, and efforts to reduce the impacts of dogs on wildlife may therefore be met by public resistance. We believe public awareness campaigns that focus on the problems created by dogs and how these problems can be avoided (e.g., keeping family dogs from roaming freely) are a necessary step for conservation actions to succeed. To date, public awareness campaigns targeting dog owners in Ikh Nart have resulted in support for dog training programs to reduce wildlife conflicts and in permission to lethally remove offending dogs when they are observed chasing wildlife. Similarly, public awareness campaigns not only resulted in public acceptance but also aided recovery efforts for kiwi because dog owners modified their behaviors in response to the campaign 
(e.g., prevented dogs from roaming overnight; Miller and Pierce 1995, Pierce et al. 2006).

\section{Policy and enforcement}

One of the simplest ways to reduce the potential for conflict between dogs and wildlife is to implement and enforce leash laws. Public awareness campaigns will enhance wildlifefriendly actions by dog owners, but not all dog owners will be persuaded to take voluntary actions. In the United States, laws already exist in most states that, if enforced, could reduce wildlife-dog interactions (Tischler 2007). Globally, policies aimed at reducing subsidization (e.g., changes to garbage storage) and reproduction (e.g., spay and neuter programs) of dogs could drastically reduce the population size of free-roaming dogs at the urban-wilderness interface.

\section{Costs}

Although our studies in Mongolia suggest that a combination of focused research and outreach can result in local support of conservation efforts that minimize effects of dogs, the associated costs may exceed available funds in many developing nations. However, these expenditures will offset the costs associated with the detrimental impacts of free-roaming and feral dogs. For example, the annual cost of a rabies vaccine program in Asia is $\$ 1.30$ (US dollars) per dog for a total of $\$ 52$ million, whereas the cost of cattle lost to rabies from dog bites is $\$ 10.6$ million and the cost of treating human infections is between \$179.8 million and \$251.7 million (Knobel et al. 2005). These costs are probably even higher after impacts to wildlife and other domestic animals are considered. The repeated introduction of pathogens from domestic dogs living in proximity to Ethiopian wolves resulted in the potentially risky act of vaccinating the wolves (Knobel et al. 2008). Rabies outbreaks from feral and freeroaming dogs represent just one detrimental impact; thus, the costs of proactively reducing the effects of free-roaming and feral dogs on wildlife probably are substantially lower than those associated with reactionary measures. Indeed, Salb and colleagues (2008) suggested that proactively testing and treating dogs for parasites could have added benefits because dogs may act as sentinels for wildlife and human health. Increasing the number of scientific studies and using these findings to inform the public through outreach programs will not only reduce costs but also facilitate recovery and maintenance of wildlife populations globally.

\section{Conclusions}

We believe our call for more directed studies, public outreach, and policy changes could greatly enhance the understanding of the impacts feral and free-roaming dogs may have on wildlife. Our case study suggests that efforts to conserve threatened and endangered species that do not include management actions aimed to reduce dog-wildlife interactions may be ineffective in areas where feral and freeroaming dogs occur. Man's best friend may not be wildlife's best steward.

\section{Acknowledgments}

Research was conducted in cooperation with the Mongolian Academy of Sciences and under animal care guidelines of Wildlife Conservation Society and Denver Zoological Foundation. We thank Kim Murray, Heath Weaver, and Todd Atwood for reviewing earlier drafts. RPR and SA were supported by the Denver Zoological Foundation, Earthwatch Institute, Mongolian Conservation Coalition, Trust for Mutual Understanding, Mongolian Academy of Sciences, the Dalanjargal Soum Administration, and the Argali Wildlife Research Center.

\section{References cited}

Atickem A, Bekele A, William SD. 2009. Competition between domestic dogs and Ethiopian wolves (Canis simensis) in the Bale Mountains National Park, Ethiopia. African Journal of Ecology 48: 401-407.

Banks PB, Bryant JV. 2007. Four-legged friend or foe? Dog walking displaces native birds from natural areas. Biology Letters 3: 611-613.

Berger J, Murray Berger K, Bergen S, Buuveibaatar B, Fine A, Lkhagvasuren B, Young JK, Zahler P. 2008. Migration bottlenecks, climate, and the conservation of Pleistocene relicts in Central Asia. Open Journal of Conservation Biology 2: 9-10.

Black HL, Green JS. 1985. Navajo use of mixed-breed dogs for management of predators. Journal of Rangeland Management 38: 11-15.

Boitani L, Francisci F, Ciucci P, Andreoli G. 1995. Population biology and ecology of feral dogs in central Italy. Pages 217-244 in Serpell J, ed. The Domestic Dog: Its Evolution, Behaviour, and Interactions with People. Cambridge University Press.

Bouvier M, Arthur CP. 1995. Protection et indemnisation des degats d'ours aux troupeaux domestiques dans les Pyrenees occidentales: Fonctionnement, importance economique et role dans la protection de l'ours. Pages 510-521 in Bourliere F, Barre V, Camerra JJ, Herrenschmidt V, Moutou F, Servheen C, Stuart S, Saint Girons MC, eds. Proceedings on the Management and Restoration of Small and Relictual Bear Populations. Museum of Natural History.

Butler JRA, du Toit JT. 2002. Diet of free-ranging domestic dogs Canis familiaris in rural Zimbabwe: Implications for wild scavengers on the periphery of wildlife reserves. Animal Conservation 5: 29-37.

Butler JRA, du Toit JT, Bingham J. 2004. Free-ranging domestic dogs Canis familiaris as predators and prey in rural Zimbabwe: Threats of competition and disease to large wild carnivores. Biological Conservation 115: 369-378.

Buuveibaatar B, Young JK, Fine AE. 2009. Mongolian saiga in Sharga Nature Reserve: Are domestic dogs a threat to saiga? Mongolian Journal of Biological Sciences 7: 37-43.

Cablk ME, Heaton JS. 2006. Accuracy and reliability of dogs in surveying for desert tortoise Gopherus agassizii. Ecological Applications 16: 1926-1935.

Campos CB, Esteves CF, Ferraz KMPMB, Crawshaw PG, Verdade LM. 2007. Diet of free-ranging cats and dogs in a suburban and rural environment, south-eastern Brazil. Journal of Zoology 273: 14-20.

Causey MK, Cude CA. 1980. Feral dog and white-tailed deer interactions in Alabama. Journal of Wildlife Management 44: 481-484.

[CDW] Colorado Division of Wildlife. 1998. Wildlife Report: Free-roaming Dogs that Pose a Threat to Wildlife. News from the Colorado Division of Wildlife. CDW. (17 November 2010; www.dnr.state.co.us/cdnr_news/ wildlife)

Ciucci P, Boitani L. 1998. Wolf and dog depredation on livestock in central Italy. Wildlife Society Bulletin 26: 504-514.

Clark EL, Munkhbat J, Dulamtseren S, Baillie JEM, Batsaikhan N, Samiya R, Stubbe M. 2006. Mongolian Red List of Mammals, Regional Red List Series, vol. 1. Zoological Society of London.

Echegaray J, Vilà C. 2010. Noninvasive monitoring of wolves at the edge of their distribution and the cost of their conservation. Animal Conservation 13: 157-161. 
Elton CS. 1958. Ecology of Invasions by Animals and Plants. University of Chicago Press.

Feldmann BM. 1974. The problem of urban dogs. Science 185: 903.

Gingold G, Yom-Tov Y, Kronfeld-Schor N, Geffen E. 2009. Effect of guard dogs on behavior and reproduction of gazelles in cattle enclosures on the Golan Heights. Animal Conservation 12: 155-162.

Green JS, Gipson PS. 1994. Feral Dogs, Prevention and Control of Wildlife Damage. Cooperative Extension Division Institute of Agriculture and Natural Resources, US Department of Agriculture Animal and Health Plant Inspection Service, Animal Damage Control, Great Plains Agricultural Council Wildlife Committee.

Green JS, Woodruff RA, Tueller TT. 1984. Livestock-guarding dogs for predator control: Costs, benefits, and practicality. Wildlife Society Bulletin 12: 44-50.

Iverson JB. 1978. The impact of feral cats and dogs on populations of the West Indian rock iguana, Cyclura carinata. Biological Conservation 14: 63-73.

Jhala YV. 1993. Predation on blackbuck by wolves in Velavadar National Park, Gujarat, India. Conservation Biology 7: 874-881.

Jhala YV, Giles RH. 1991. The status and conservation of the wolf in Gujarat and Rajasthan, India. Conservation Biology 5: 476-483.

Kenny DE, DeNicola AJ, Amgalanbaatar S, Namshir Z, Wingard G, Tuya T, Reading RP. 2008. Three field capture techniques for free-ranging argali sheep Ovis ammon in Mongolia. Zoological Biology 27: 137-144.

Khan MM. 2009. Can domestic dogs save humans from tigers Panthera tigris? Oryx 43: 44-47.

Knobel DL, Cleaveland S, Coleman PG, Fèvre EM, Meltzer MI, Miranda ME, Shaw A, Zinsstag J, Meslin FX. 2005. Re-evaluating the burden of rabies in Africa and Asia. Bulletin of the World Health Organization 83: 360-368.

Knobel DL, Fooks AR, Brookes SM, Randall DA, Williams SD, Argaw K, Shiferaw F, Tallents LA, Laurenson MK. 2008. Trapping and vaccination of endangered Ethiopian wolves to control an outbreak of rabies. Journal of Applied Ecology 45: 109-116.

Kruuk H, Snell H. 1981. Prey selection by feral dogs from a population of marine iguanas Amblyrhynchus cristatus. Journal of Applied Ecology 18: $197-204$.

Lacerda ACR, Tomas WM, Marinho-Filho J. 2009. Domestic dogs as an edge effect in the Brasília National Park, Brazil: Interactions with native mammals. Animal Conservation 12: 477-487.

Laurenson MK, Sillero-Zubiri C, Thompson H, Shiferwa F, Thirgood T, Malcolm JR. 1998. Disease threats to endangered species: Ethiopian wolves, domestic dogs, and canine pathogens. Animal Conservation 1: 273-280.

Lenth B, Knight R, Brennan ME. 2008. The effects of dogs on wildlife communities. Natural Areas Journal 28: 218-227.

Long RA, Donovan TM, Mackay P, Zielinski WJ, Buzas JS. 2007. Effectiveness of scat detection dogs for detecting forest carnivores. Journal of Wildlife Management 71: 2007-2017.

Lowry DA, McArthur KL. 1978. Domestic dogs as predators on deer. Wildlife Society Bulletin 6: 38-39.

MacPherson CN. 2005. Human behavior and the epidemiology of parasitic zoonoses. International Journal of Parasitology 35: 1319-1331.

Mamaev LV, et al. 1995. Characterization of morbilliviruses isolated from Lake Baikal seals (Phoca sibirica). Veterinary Microbiology 44: 251-259.

Manor RD, Saltz D. 2004. The impact of free-roaming dogs on gazelle kid/ female ratio in a fragmented area. Biological Conservation 119: 231-236.

Mech DL. 1988. The Arctic Wolf: Living with the Pack. Voyageur.

Meek PD. 1999. The movement, roaming behaviour and home range of free-roaming domestic dogs, Canis lupus familiaris, in coastal New South Wales. Wildlife Research 26: 847-855.

Miller JE, Leopold BD. 1992. Population influences: Predators. Pages 119-128 in Dickinson JG, ed. The Wild Turkey: Biology and Management. Stackpole.

Miller PJ, Pierce RJ. 1995. Distribution and decline of the North Island brown kiwi Apteryx australis mantelii in Northland. Notornis 42: 203-211.
Mitchell BD, Banks PB. 2005. Do wild dogs exclude foxes? Evidence for competition from dietary and spatial overlap. Australian Ecology 30: 581-591.

[NASS] National Agricultural Statistics Service. 1995. Sheep and Goat Predator Loss. US Department of Agriculture, NASS.

Newsome A. 1990. The control of vertebrate pests by vertebrate predators. Trends in Ecology and Evolution 5: 187-191.

O’Brien TG, Kinnaird MF, Wibisono HT. 2003. Crouching tigers, hidden prey: Sumatran tiger and prey populations in a tropical forest landscape. Animal Conservation 6: 131-139.

Olson KA, Fuller TK, Schaller GB, Lhagvasuren B, Odonkhuu D. 2005. Reproduction, neonatal weights, and first-year survival of Mongolian gazelles Procapra gutturosa. Journal of Zoology 265: 227-233.

Patronek GJ. 1998. Free-roaming and feral cats-their impact on wildlife and human beings. Journal of the American Veterinary Medical Association 212: 218-226.

Pierce RJ, Sporle W. 1997. Causes of Kiwi Mortality in Northland. Conservation Advisory Science Notes no. 169. Department of Conservation, Wellington, New Zealand.

Pierce RJ, Gardiner C, Moodie H, Robertson HA, Sporle W. 2006. Sustainable Management of Brown Kiwi and Other Threatened Birds in Northland. Wildlands Contract Report no. 1193. Department of Conservation, Wellington, New Zealand.

Prakash V, Pain DJ, Cunningham AA, Donald PF, Prakash N, Verma A, Gargi R, Sivakumar S, Rahmani AR. 2003. Catastrophic collapse of Indian white-backed Gyps bengalensis and long-billed Gyps indicus vulture populations. Biological Conservation 109: 381-390.

Prugh LR, Stoner CJ, Epps CW, Bean WT, Ripple WJ, Laliberte AS, Brashares JS. 2009. The rise of the mesopredator. BioScience 59: 779-791.

Ralls K, White PJ. 1995. Predation on San Joaquin kit foxes by larger canids. Journal of Mammalogy 76: 723-729.

Reading RP, Amgalanbaatar S, Kenny D, Onon Y, Namshir Z, DeNicola A. 2003. Argali ecology in Ikh Nartiin Chuluu Nature Reserve: Preliminary findings. Mongolian Journal of Biological Science 1: 3-14.

Reading RP, Amgalanbaatar S, Wingard GJ, Kenny D, DeNicola A. 2005. Ecology of argali in Ikh Nartiin Chuluu, Dornogobi Aimag. Erforschung Biologischer Ressourcen der Mongolei (Halle/Saale) 9: 77-89.

Salb AL, Barkema HW, Elkin BT, Thompson RCA, Whiteside DP, Black SR, Dubey JP, Kutz SJ. 2008. Dogs as sources and sentinels of parasites in humans and wildlife, northern Canada. Emerging Infectious Disease 14: 60-63.

Schaller G. 1998. Wildlife of the Tibetan Steppe. University of Chicago Press.

Sillero-Zubiri C, Gotelli D. 1994. Canis simensis. Mammal Species 485: $1-6$.

Sludskii AA. 1962. The relationship between predator and prey. Proceedings of the Zoological Institute of the Kazakhstan Academy of Science 17: 24-143.

Taborsky M. 1988. Kiwis and dog predation: Observations at Waitangi State Forest. Notornis 35: 197-202.

Timm RM, Schmidt RH. 1989. Management problems encountered with livestock guarding animals at the University of California, Hopland Field Station. Great Plains Wildlife Damage Control Workshop 9: 54-58.

Tischler J. 2007. Table of state and federal laws concerning dogs chasing wildlife. Animal Legal Defense Fund. Michigan State University College of Law. (17 November 2010; www.animallaw.info/articles/ arusdogschasewildlifetable.htm)

Torres SG, Mansfield TM, Foley JE, Lupo T, Brinkhaus A. 1996. Mountain lion and human activity in California: Testing speculations. Wildlife Society Bulletin 24: 451-460.

Vanak AT, Gompper ME. 2009. Dogs Canis familiaris as carnivores: Their role and function in intraguild competition. Mammal Review 39: 265-283.

Vanak AT, Thaker M, Gompper ME. 2009. Experimental examination of behavioural interactions between free-ranging wild and domestic canids. Behavioural Ecology and Sociobiology 64: 279-287. 
[WHO-WSPA] World Health Organization and World Society for the Protection of Animals. 1990. Guidelines for Dog Population Management. WHO.

Williams CL, Blejwas K, Johnston JJ, Jaeger MM. 2003. A coyote in sheep's clothing: Predator identification from saliva. Wildlife Society Bulletin 31: 926-932.

Woodroffe R. 1999. Managing disease threats to wild mammals. Animal Conservation 2: 185-193.

Zimmerman B, Wabakken P, Sand H, Pedersen HC, Liberg O. 2007. Wolf movement patterns: A key to estimation of kill rate? Journal of Wildlife Management 71: 1177-1182.
Julie K. Young (julie.k.young@aphis.usda.gov) is with the Predator Research Station at the US Department of Agriculture, Wildlife Services, National Wildlife Research Center and the Department of Wildland Resources at Utah State University in Logan and the Institute for Wildland Studies. Kirk A. Olson is with the Department of Natural Resources Conservation at the University of Massachusetts, in Amherst. Richard P. Reading is with the Department of Conservation Biology at the Denver Zoological Foundation. Sukh Amgalanbaatar is with the Institute of Biology at the Mongolian Academy of Sciences in Ulaanbaatar. Joel Berger is with the Division of Biological Sciences, University of Montana, in Missoula, and the Wildlife Conservation Society in Missoula, Montana.

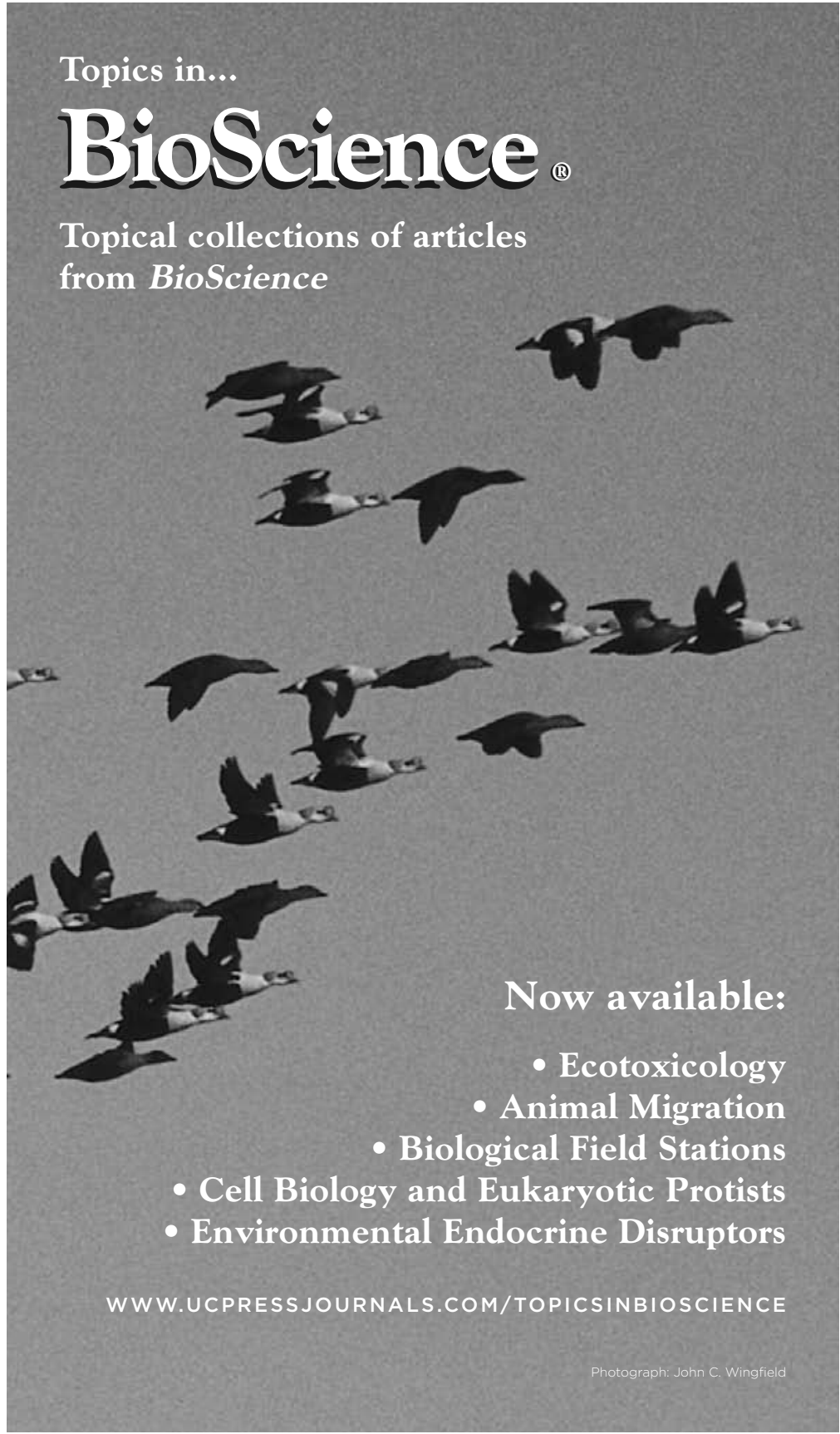

